\title{
Pragmatically on the sense of taste - a short treatise based on culinary art
}

\author{
Marek Waluga ${ }^{1}$, Krzysztof Jonderko², Magdalena Buschhaus ${ }^{3}$ \\ ${ }^{1}$ Department of Gastroenterology and Hepatology, Medical University of Silesia, Katowice, Poland \\ 2Department of Basic Biomedical Science, School of Pharmacy in Sosnowiec, Medical University of Silesia, Katowice, Poland \\ ${ }^{3}$ Centre for Therapeutic Discovery, Medical Research Council Technology, London, UK
}

Prz Gastroenterol 2013; 8 (6): 338-344 DOI: $10.5114 /$ pg.2013.39915

Key words: bitter taste, taste, salty taste, sour taste, sweet taste, taste receptors, umami taste.

Address for correspondence: Marek Waluga MD, PhD, Department of Gastroenterology and Hepatology, Medical University of Silesia, 14 Medyków St, 40-752 Katowice, Poland, phone: +48 3278944 01, fax: +48 3278944 02, e-mail: marekwaluga@poczta.onet.pl

\begin{abstract}
The sense of taste is essential for proper functioning of the organism. The authors describe, in an accessible way, the complex mechanisms of taste perception. The structure of particular taste receptors, variants of their activation, as well as physical and chemical factors modifying the sensation of taste, are presented. Exquisite culinary examples are given in order to facilitate the reader with the understanding of why, at the level of the cerebral cortex, a virtually infinite number of combinations of taste sensations can be perceived. The discourse is spiced up by reflections of the eminent philosopher of taste, J.A. Brillat-Savarin, who convinces us that food intake should be not only a physiological act, but also a refined pleasure.
\end{abstract}

\section{Introduction}

Dis moi ce que tu manges, je te dirai qui tu es. (Tell me what you eat, and I'll tell you who you are.) Jean Anthelme Brillat-Savarin

Taste, together with four other senses (smell, hearing, touch, sight), allows individuals to orient themselves in their surrounding environments. Apparently there can be another channel of perception, the socalled "sixth sense", but its ephemeral nature effectively evades speculations in keeping with medical standards based on facts. Over thousands of years of evolution, the sense of taste has enabled our ancestors to distinguish between edible and inedible, and even toxic food. Today, it plays a much more complex role.

The economic sector for which the progress in research on taste has unprecedented importance is the food industry. Various flavour additives are aimed at increasing the attractiveness of food and thus increasing its sales, and undoubtedly having an effect on the economic development of the food industry. The importance of taste is evident in the fact that many, almost identical, food products only differ in their flavour.
A testament to this is that food manufacturers consider taste as one of the most important determinants of the demand for a product. Care is taken that any other additives, such as preservatives, do not negatively impact on taste. The "battle" for the best flavour is a professional goal for many food manufacturers' employees.

Taste also plays a role in medicine. Many patients with gastroenterological and neurological disorders have taste impairment. Improvements in the taste of food are beneficial for patients' nutrition. It is not surprising, then, that manufacturers of nutrient supplements - in addition to alimentary qualities of the product - give precedence to flavour. The target audience of these efforts also includes paediatric patients. A small child does not consider the nutritional value of food, but its taste. Therefore, in the production of various kinds of baby food the manufacturers pay special attention to the right flavour selection.

Pleasant taste can also have negative implications - increasing the desire for food consumption, affecting the rate and the quantity of meals. The social consequence of this is the overwhelming obesity epidemic observed in developed countries. 
For the above reasons, research on the sensation of taste can be considered to be an important element in the study about nutrition of healthy, as well as unwell people. So far, this aspect of nutrition has been ignored in textbooks or treated marginally.

\section{The hedonistic aspect of taste: the Polish art of cooking}

With the aim of making the discussion on receptors, bio-signals, conjugations and genes enabling perception of taste sensation more accessible, or colloquially "digestible", to the reader, let's move to one of the notable restaurants in the royal city of Krakow (however, in order to avoid being accused of surreptitious advertising, we omit its name). Among the guests one can spot the regulars who are accustomed to inter-continental cuisine. The waiters serve all sorts of traditional Polish cuisine and also very exotic dishes. The quality of the dishes served delights the guests with their broad variety, colours, smells, and tastes. It is puzzling just how many unique types of food can be found on the plates ... and why so many? Surely to secure the energy, metabolic and other biological needs, it would suffice to have a few or at most several types of food. Thus, probably for pleasure... To please the senses with the pleasure of eating. It is an undeniable thing. Senses and stimuli perceived by them shape our attitude to the environment, well-being, and allow us to enjoy the pleasures in life. Therefore, unsurprisingly, culinary art bears the name "art". Similarly to classical art - painting, sculpture, architecture, and music - it exists to bring us pleasure. However, classical art mainly stimulates the sense of sight or hearing, while culinary art stimulates the sense of smell and taste in addition to the visual sense [1].

\section{La destinée des nations dépend de la manière dont elles se nourrissent. \\ (The destiny of nations depends on how they feed.) Jean Anthelme Brillat-Savarin}

Every nation loves its own cuisine and treats it as an important part of culture and national heritage. $\mathrm{Cu}$ linary art reflects the individuality of the nation and often acts as an element of national pride.

Polish cuisine has a rich history. Highly appreciated Italian and French cuisine as well as German, Jewish and oriental cuisine influences can also be seen, in addition to the typical national Polish elements. The influence of other cultures on the Polish cuisine mostly depended on what was currently happening in the royal courts. A particularly strong impact on Polish cuisine goes back to the time of the arrival in Poland of Queen Bona, who introduced new culinary traditions. First of all, elements of Mediterranean cuisine, slightly lighter than the traditional Polish cuisine, with a large addition of fruits and vegetables, were adopted. In the Polish tradition very significant is the influence of French cuisine. Some delicacies, such as jellies, pâtés, casseroles and stuffing, are clearly French in origin. French cuisine brought more diversity to Polish menus and the meals became more delicate.

Geographical discoveries of the fifteenth and sixteenth centuries led to oriental elements appearing in the recipes of many European countries, including Poland. The essential element is the widespread use of root spices which have significantly diversified the flavour of many dishes. Products such as dried fruits and nuts, preserves, poppy seeds, buckwheat, halva, or Christmas Eve specialties like kutia and almond soup, have their origin in oriental cuisine.

During the partition of Poland by Russia, AustriaHungary and Germany, the cuisines of these countries had an important influence on the Polish way of cooking. In the land under Austrian jurisdiction, in the former Galicia, Hungarian goulash, aubergine and peppers became popular. Knuckles or yeast cakes are primarily the result of German influence, particularly seen in Greater Poland (Wielkopolska).

A significant Jewish influence on Polish dishes was observed between the First and Second World War. Cabbage with raisins, plaited sweet breads ("chatka" in Polish) and new ways in preparation of many fish dishes are the effects of mixing of Jewish culinary traditions with Polish cuisine.

\section{The confusion of flavours and physiology \\ Pour avoir de l'âme, il faut avoir du goût. (To have a soul, you must have taste.) Jean Anthelme Brillat-Savarin}

During our discussion about the Polish culinary art, at the next table an intriguing dish has appeared: salad in white pancakes with spinach, strawberry and shrimp (sample recipe available on http://www.kwestiasmaku. com). Let us think, what could it taste like? Why, it is a mixture of various ingredients. In particular, spinach, which might be tasty to some, is not as appealing to others. Is it possible to correlate the fact of not liking spinach, or Brussels sprouts, with the preference for weak tea instead of coffee? Well, yes! The people who have such an aversion show sensitivity (Tt) or su- 
per-sensitivity (TT) to 6-n-propylthiouracil (PROP), which is a feature dependent on the dominant T gene [2]. Individuals sensitive to PROP avoid hot and spicy foods [3], and bitter and sweet substances are likely to cause them an adverse experience [4, 5].

In the meantime, at another table a lively discussion has started. One of the guests ordered an oriental dish with the addition of cayenne pepper, and immediately, after finishing, he began to eat a fruit salad, asking, "Why is it excessively sweetened? Are not fruits by themselves sweet enough?" Someone sitting nearby replied, "You have eaten a chili seasoned dish, and it is not surprising that now you do not sense taste adequately." Indeed, the taste of cayenne pepper is extremely strong and can interfere with the perception of other taste sensations. Capsaicin, contained in cayenne pepper, is the substance responsible for this, as it affects thermo-responsive TRPV1 receptors. They have the characteristics of nociceptors which, when activated, release vasodilatory substances, such as calcitonin gene-related peptide (CGRP) and substance P. They raise tongue temperature [6], which could increase the sensation of sweet taste [7].

Another guest, who had just drunk hot tea moments before, also found that the salad was overly sweet. "You might have burned your tongue", replied his meal companion. He was partly right, because the outer temperature can also modify the taste sensation [8]. Heating the front section of the tongue causes a sweet taste sensation. This phenomenon results from temperature sensitivity of TRPM 5 channels in that section of the tongue containing sweet taste receptors T1R2/T1R3 [9]. Other thermo-receptors, such as TRPM8, are activated by menthol and give a cooling sensation [10], while TRPV3 is activated by oregano, spicy and hot flavours, cloves and thyme [11].

Finally, we get our long-awaited meal - leg of lamb with rosemary and garlic, baked in white wine with onions (sample recipe available on http://www.kwestiasmaku.com). Visually perfect, pinkish flesh when cut, with perfectly composed flavours. Now, how does it happen that with the five basic tastes (sweet, salty, sour, bitter, umami), we are able to perceive complex flavour compositions, which, due to lack of opportunities for precise verbalization, we are often inclined to summarize as "heaven in the mouth", or even state in a very simplified way that the dish tastes greasy, watery, sour, pungent, spicy, etc. All this is because the solid or liquid food in the oral cavity causes a response from the other systems that monitor the temperature, or texture of the food. These non-specific features are not received by specific receptors. These sensations arise from co-activation of taste cells and specialized nerve endings surrounding the taste buds, originating from the trigeminal, glossopharyngeal and vagal nerves. These nerve endings represent different classes of mechano- and chemoreceptors that receive information about the thermal, chemical and physical characteristics of food [6].

\section{Salty and sour taste}

Le nombre des saveurs est infini.

(The number of flavours is infinite.) Jean Anthelme Brillat-Savarin

The simplest mechanism of perception is that of salty taste, since it has no specific receptors $[12,13]$. Sodium ions interact directly with the open epithelial sodium channels (ENaC), causing a change in their potential [14-17], followed by an influx of calcium ions, release of neurotransmitters and generation of a series of action potentials [18]. There are sodium-selective channels sensitive and non-sensitive to amiloride, whose operation can be controlled, amongst others, by hormones responsible for electrolyte balance $[16,19,20]$. Therefore, it is understandable why at the beginning of a meal those guests who add more salt are forced to leave the table and go to the restroom more often as their body is forced to get rid of excess salt. Mechanisms of physiological regulation, however, cause the salty taste receptors to become more sensitive as the meal continues, reducing the need for additional salt, so the necessity to leave the table becomes less frequent.

Sprinkling of fresh water fish with lemon juice has become almost a custom. You can ask perversely, why lemon but not, for example, sauerkraut juice? Obviously both are strongly sour. This is because, although the hydrogen ions $\left(\mathrm{H}^{+}\right)$are mainly responsible for the perception of sour flavour [21], the anions of the corresponding acids have an additional effect on the final perception [22]. Anions are active agents, which can interact and regulate the activity of other channels. Currently several mechanisms of acid signal transduction are taken into consideration [23]: a) direct blockage of potassium channels by protons, $b$ ) the flow of protons through $\mathrm{ENaC}, \mathrm{c}$ ) activation of acid-sensing ion channels (ASICs), d) activation of specific chloride channels that can alter membrane potential and accumulation of neurotransmitters in the synaptic vesicles, e) activation of ion channels gated by cyclic nucleotides, f) intracellular acidosis. Fortunately, one does not have to remember all this while eating a sour salad with parsnip (sample recipe available on http://www.kuchnia-polska.net), which has just been served. 


\section{Bitter taste}

A popular method to increase appetite is serving guests with a small amount of bitter aperitif before a meal. Widely known bitter liqueur, used for the same purpose is tinctura amara - made from the wormwood herb, bitter orange core, bogbean leaf (Menyanthes trifoliata), and calamus rhizome. Listed in the ingredients, Menyanthes trifoliata contains bitter glycoside menyanthin and other substances with a bitter taste, which stimulate taste receptors, and through the central nervous system, this stimulation increases the secretion of gastric juice and saliva, facilitating digestion.

Bitter taste receptors are numerous; there are about 60 of them. This family of receptors is denoted as T2R and these receptors belong to $\mathrm{G}$-protein-coupled-receptors (GPCR). Stimulation of these receptors activates a protein G-dependent cascade. This leads to activation of subunit $\beta 2$ of phospholipase C (PLC $\beta 2$ ), which hydrolyses phosphatidylinositol-4,5-bisphosphate, resulting in the formation of grade II transmitters - inositol triphosphate $\left(\mathrm{IP}_{3}\right)$ and diacylglycerol (DAG). Of main importance is $I P_{3}$, which causes the release of calcium from the endoplasmic reticulum, the opening of the non-selective monovalent cation channels, the release of neurotransmitters and the depolarization of taste cells [24-26]. Diacylglycerol activates protein kinase C, which phosphorylates many intracellular proteins, including those gating ion channels. Protein $\mathrm{G}$ also affects the balance between phosphodiesterase and adenylate cyclase, and consequently the levels of cyclic nucleotides and protein kinase $A$, which modulates the flow of ions through ion channels, by changing membrane potential.

\section{Sweet and umami taste}

A pleasure in itself, but actually only affirming the awaited taste sensation, is studying the wine list [27]. Traditionally most of the guests select lighter white wines to accompany dishes with a delicate flavour and dominant taste of umami, such as white fish or chicken in broth. But it is difficult to imagine enjoying the Argentinean bife de chorizo, or Italian osso buco alla Milanese, without reaching for a full bodied red wine, such as Argentinean Malbec, Uruguayan Tannat or Chilean Carmenere.

Meanwhile, someone at the nearby table, while eating sweet jelly, sips occasionally on a small amount of wine. On the face of it, this seems a profanation, because essentially all wines seem to us just sour, when served with sweet food. We notice, however, that he is drinking very sweet Moscato d'Asti, whose bouquet definitely dominates the flavour of the jelly. It is not a secret for connoisseurs that the mouldy French cheeses or the famous foie gras are best accompanied by sweet wines, with a clear preference for the French Sauternes or German Beerenauslese.

The optimal selection of wines to complement a dish is a great art, due to the great complexity of the physiological interactions of taste receptors. Sweet taste receptors and the umami type are in fact structurally related and equally complex as bitter receptors, even though the stimuli received are entirely different when it comes to the degree of pleasure. Like bitter receptors, they belong to the GPCR type receptors. A few sweet receptor homodimers have been identified T1R1, T1R2 and T1R3 - with the latter being primarily responsible for the perception of this taste $[23,28]$. Some studies indicate that T1R2/T1R3 heterodimer is responsible for the sweet taste perception, at least at moderate concentrations of substances [23, 29]. Different mechanisms are activated depending on the type of sweet substances. In the case of simple carbohydrates, GPCR stimulation activates adenylate cyclase that increases the amount of CAMP, which directly or indirectly (through CAMP-dependent protein kinase - PKA) phosphorylates and closes the basolateral potassium channels. Potassium ion permeability in the receptor cell membrane decreases, which modifies depolarization, leading to excitation of a series of functional potentials in sensory neurons. Sucrose also increases the concentration of intracellular calcium ions $\left(\mathrm{Ca}^{2+}\right)$.

Synthetic sweet substances such as saccharin and D-amino acids activate another type of GPCR receptors that stimulate phospholipase $C$, increasing the amount of $\mathrm{IP}_{3}$ and DAG and acting further in the same way as in the bitter receptor. Both activation pathways can coexist within the same taste receptor [30, 31].

Interestingly, the heterodimer T1R1/T1R3 responsible for the reception of sweet taste can also receive the umami taste as well. The name of this fifth taste comes from Japan and means delightful, or delicious. This is the taste of food such as chicken broth, fish meat, some vegetables (tomato), matured cheese [32, 33] and in the more sophisticated dishes, for example monkfish skewers with bay leaf and pasta (sample recipe available on http://www.kwestiasmaku.com). These contain sodium glutamate and 5'-ribonucleotides, such as inosine monophosphate or GMP. The receptor for umami taste, belonging to metabotropic glutamate receptors (mGluR4), was discovered in 2000 in the brain [33, 34] and it is so far the last known main receptor of basic tastes. In addition to it, the ionotropic receptors [35], the previously mentioned T1R1/T1R3 heterodimer, are also involved in umami taste perception $[36,37]$. 


\section{The sense of taste and motor activity of the gastrointestinal tract}

La nourriture est toutes les substances qui, soumises à l'estomac, peuvent s'animaliser par la digestion, et réparer les pertes que fait le corps humain par l'usage de la vie.

(Food is any substance that, when subjected to the stomach, can come to life through digestion, repairing damage in the human body arising from enjoyment of life.) Jean Anthelme Brillat-Savarin

Taste information is conducted from the base of the taste bud to the taste centres through afferent neuron fibres of three cranial nerves: from 2/3 of the front region of the tongue, cheek wall, and the sublingual area through the branches of the facial nerve (VII), from $1 / 3$ of the tongue's posterior part and the tongue base, and part of the oropharynx by the glossopharyngeal nerve (IX), from the larynx and pharynx by the vagus nerve $(X)$. The nerve ganglia of these three cranial nerves contain the first sensory neuron, while the nucleus of the solitary tract contains the second sensory neuron. From that point the nerve fibres run in the medial lemniscus (lemniscus medialis) to the ventral posteromedial nucleus of the thalamus, where the third neuron is located. The fourth neuron is found in the sensory cortex within the primary sensory representation of the oral cavity in the postcentral gyrus and insula [37-41].

It can be deduced that the innervation of taste receptors is very rich. Interestingly, attention is drawn to the contribution of sensory fibres of the vagus nerve, the receiver of taste sensations from the larynx and pharynx regions. Hence the presence of a reflex arc involving receptors for that taste and efferent fibres of the vagus nerve, and their effect on gastrointestinal motility, cannot be excluded. It seems that, since the pioneering investigations by Pawlow [42], there is in fact a lack of such studies, despite the number of inquiries on the effect of feeding on physiological gastrointestinal tract functions. An increase in saliva [43], gastric juice [44, 45], pancreatic enzymes [46] or insulin [47] secretion was observed under the influence of sham feeding. Sham feeding with appetizing food resulted, in approximately one-third of the maximum gastric secretion obtained by the combined use of sham feeding, food and stomach distension [48], whereas there was no increase in gastric juice [44], or insulin [49] secretion, when unappetizing food was used.

It is worth asking ourselves whether stimulation with the right flavour or combination of flavours may improve the adaptation of the gastric fundus to the meal volume or affect the rate of stomach emptying into the duodenum. The so-called everyday observations indicate that bitter taste increases salivary secretion, and bitter tinctures reduce postprandial fullness in the upper abdomen. The first systematic study on the effects of exposure to bitter taste was done by Prof. R. Spiller's team, which indicated that the bitter taste of quinine sulfate, compared with a pleasant taste of strawberries, caused a decrease in the rate of gastric emptying of low-calorie liquid, and slightly reduced the postprandial increase in power of slow waves in the electrogastrographic records [50]. The observations cited above were consistent with the studies by Katschinski et al. [45], and Pouderoux et al. [51], who showed that a pleasant taste during sham feeding stimulates contractions of the gastric antrum.

In another study, Prof. R. Stern's team studied the impact of appetizing and unappetizing food on gastric myoelectric activity [52]. Healthy volunteers underwent a sham feeding session - the first group received to chew delicious, cooked frankfurters, while the second group had an unappetizing, cold sausage substitute, made from tofu. In the first group, chewing a delicious meal, a significant increase in the relative contribution of normogastria in the power spectral density vector was observed. In comparison to real feeding this increase lasted for a brief period and was maintained only during the session of sham feeding. An opposite effect - a significant reduction in the relative contribution of normogastria in the power spectral density vector - was observed in the second group exposed to the unpleasant meal. In conclusion, Stern et al. suggested that sensory perception of unappetizing foods may hinder motor function of the gastrointestinal tract by inhibiting the cephalic-vagal reflex [52].

A number of new findings resulted from a recently performed prospective study on the impact of four tastes on the gastric motor activity, using an original exposure technique with agar cubes containing chemical compounds tasting of sweet, salty, sour or bitter in a concentration of one hundred times the designated individual taste recognition threshold [53], and multi-channel gastric myoelectric activity recording. Three flavours were subjectively evaluated as definitely unpleasant in comparison to the sweet taste in the order of ranking: bitter > salty > sour. Exposure to bitter and salty taste during the interdigestive phase resulted in an increase of the relative contribution of tachygastria and the decrease of normogastria in the spectral power density vector while decreasing the average degree of slow wave coupling. The bitter taste also caused a decrease in dominant frequency, and the sour taste caused a reduction of the dominant frequency in the electrogastrographic record. These observations 
led to the statement that the consistent ranking of the degree of gastric myoelectric activity impairment and subjectively perceived aversion seems to document the evolutionary archetype of the human body warning response to the taste of bitter, salty and sour flavours [53]. However, flavour stimulation did not modify the postprandial gastric myoelectric activity pattern, or stomach emptying rate of solid food. Hence it can be deduced that meal consumption elicits a protective effect against impaired gastric myoelectric activity induced by exposure to unpleasant flavours. This observation is similar to that reported previously in studies on experimental stressors, in which the protective ("anti-stress") effect of food intake on the impact of stress during the interdigestive period, leading to destabilization of functional integrity of the gastrointestinal tract, has been well documented [54-56].

In conclusion, the positive implication which can be inferred is that the indulgence in gourmet food, accompanied by stimulation of the senses, especially taste stimulation by complex flavours, enables us to unwind from the stress of our everyday hectic lifestyles. Furthermore, we have to agree with the French philosopher of taste, Jean Anthelme Brillat-Savarin, quoted several times earlier in this article, that "Le plaisir de manger est le seul qui, pris avec modération, ne soit pas suivi de fatigue" ("The pleasure of eating is the only one that, when taken in moderation, is not followed by fatigue") [57].

\section{References}

1. Szymanderska H. Encyklopedia polskiej sztuki kulinarnej, Wydawnictwo REA, Warszawa 2003.

2. Drewnowski A, Henderson S, Barratt-Fornell A. Genetic taste markers and food preferences. Drug Metab Dispos 2001; 29: 535-8.

3. Karrer T, Bartoshuk L. Effects of capsaicin desensitization on taste in humans. Physiol Behav 1995; 57: 421-9.

4. Bartoshuk LM, Duffy VB, Miller IJ. PTC/PROP Tasting: anatomy, psychophysics and sex effects. Physiol Behav 1994; 56: 1165-71.

5. Gent JF, Bartoshuk LM. Sweetness of sucrose, neohesperidin dihydrochalcone and saccharin is related to the genetic ability to taste the bitter substance 6-n-propylthiouracil. Chem Senses 1983; 7: 265-72.

6. Wang Y, Erickson RE, Simon SA. Modulation of chorda tympani nerve activity by lingual nerve stimulation. J Neurophysiol 1995; 73: 1468-83.

7. Cruz A, Green BG. Thermal stimulation of taste. Nature 2000; 403: 889-92.

8. Bartoshuk LM, Rennert K, Rodin J, Stevens JC. Effects of temperature on the perceived sweetness of sucrose. Physiol Behav 1982; 28: 905-10.

9. Simon SA, de Araujo IE, Gutierez R, Nicolelis MA. The neural mechanisms of gestation: a distributed processing code. Nat Rev Neurosci 2006; 7: 890-901.
10. Chuang HH, Neuhausser WM, Julius D. The super-cooling agent icillin reveals a mechanism of coincidence detection by a temperature-sensitive TRP channel. Neuron 2004; 43: 859-69.

11. Xu H, Delling M, Jun JC, Clapham DE. Oregano, thyme and clove-derived flavors and skin sensitizers activate specific TRP channels. Nat Neurosci 2006; 9: 628-35.

12. Lindemann B. Receptors and transduction in taste. Nature 2001; 413: 219-25.

13. Lindemann B. Sodium taste. Curr Opin Nephrol Hypertens 1997; 6: 425-9.

14. Schiffman SS, Lockhead E, Maes FW. Amiloride reduces the taste intensity of $\mathrm{Na}+$ and $\mathrm{Li}+$ salts and sweeteners. Proc Natl Acad Sci USA 1983; 80: 6136-40.

15. Lin W, Finger TE, Rossier BC, Kinnamon SC. Epithelial Na+ channel subunits in rat taste cells: localization and regulation by aldosterone. J Comp Neurol 1999; 405: 406-20.

16. Kretz O, Barbry P, Bock R, Lindemann B. Differential expression of RNA and protein on the three pore-forming subunits of the amiloride-sensitive epithelial sodium channel in taste buds of the rat. J Histochem Cytochem 1999; 47: 51-64.

17. Li XJ, Blackshaw S, Snyder SH. Expression and localization of amiloride-sensitive sodium channel indicate a role for nontaste cells in taste perception. Proc Natl Acad Sci USA 1994; 91: 1814-8.

18. Kellenberger S, Schild L. Epithelial sodium channel/degenerin family of ion channels: a variety of functions for a shared structure. Physiol Rev 2002; 82: 735-67.

19. Canessa CM, Schild L, Buell G, et al. Amiloride-sensitive epithelial $\mathrm{Na}+$ channel is made of three homologous subunits. Nature 1994; 367: 463-7.

20. Avenet P, Lindemann B. Noninvasive recording of receptor cell action potentials and sustained currents from single taste buds maintained in the tongue: the response to mucosal $\mathrm{NaCl}$ and amiloride. J Membr Biol 1991; 124: 33-41.

21. Kim UK, Breslin P, Reed D, Drayna D. Genetics of human taste perception. J Dent Res 2004; 83: 448-53.

22. Lindemann B. Taste reception. Physiol Rev 1996; 76: 718-66.

23. Breslin PA, Huang L. Human taste: peripheral anatomy, taste transduction, and coding. Adv Otorhinolaryngol 2006; 63: 152-90.

24. Prawitt D, Monteilh-Zoller MK, Brixel L, et al. TRPM5 is a transient $\mathrm{Ca2}+$-activated cation channel responding to rapid changes in [Ca2+] Proc Natl Acad Sci USA 2003; 100: 15166-71.

25. Liu D, Liman ER. Intracellular Ca2+ and the phospholipid PIP2 regulate the taste transduction ion channel TRPM5. Proc Natl Acad Sci USA 2003; 100: 15160-5.

26. Hofmann T, Chubanov V, Gudermann T, Montell C. TRPM5 is a voltage-modulated and $\mathrm{Ca} 2+-$ activated monovalent selective cation channel. Curr Biol 2003; 13: 1153-8.

27. Kasicka-Jonderko A. Alcohol and the digestive system - should it always be blamed? Prz Gastroenterol 2012; 7: 264-75.

28. Zhang Y, Hoon MA, Chandrashekar J, et al. Coding of sweet, bitter, and umami tastes. Different receptor cells sharing similar signaling pathways Cell 2003; 112: 293-301.

29. Nelson G, Hoon MA, Chandrashekar J, et al. Mammalian sweet taste receptors. Cell 2001; 106: 381-90. 
30. Katz DB, Nicolelis MA, Simon SA. Nutrient tasting and signaling mechanisms in the gut IV. There is more to taste than meets the tongue. Am J Physiol Gastrointest Liver Physiol 2000; 278: G6-9.

31. Bernhardt SJ, Naim M, Zehavi U, Lindemann B. Changes in IP3 and cytosolic Ca2+ in response to sugars and non-sugar sweeteners in transduction of sweet taste in the rat. J Physio (Lond.) 1996; 490: 325-36.

32. Kurihara K, Kashiwuyanagi M. Physiological studies on umami taste. J Nutr 2000, 130 (Suppl. 4S): 931-4.

33. Lindemann B, Ogiwura Y, Ninomiya Y. The discovery of umam (letter). Chem Senses 2002; 27: 843-4.

34. Halpern B. What's in a name? Are MSG and umami the same? Chem Senses 2002; 27: 845-6.

35. Chaudhari N, Yang $\mathrm{H}$, Lamp C, et al. The taste of monosodium glutamate: membrane receptors in taste buds. J Neurosci 1996; 16: 3817-26.

36. Damak S, Rong M, Yasumatsu K, et al. Detection of sweet and umami taste in the absence of taste receptor T1r3. Science 2003; 301: 850-3.

37. Li X, Staszewski L, Xu H, et al. Human receptors for sweet and umami taste. Proc Natl Acad Sci USA 2002; 99: 4692-6.

38. Dodd J, Kelly JP. Trigeminal system. In: Principles of neural science. Kandel ER, Schwartz JH, Jessell TM (eds.). Elsevier, New York 1995; 701-10.

39. Saper CB. Brain stem, reflexive behavior, and the cranial nerves. In: Principles of neural science. Kandel ER, Schwartz JH, Jessell TM (eds.). McGraw-Hill, New York 2000; 873-88.

40. Bradley RM, Mistretta CM, Nagai T. Demonstration of sensory innervation of rat tongue with anterogradely transported horseradish peroxidase. Brain Res 1986; 367: 364-7.

41. Koga T, Bradley RM. Biophysical properties and responses to neurotransmitters of petrosal and geniculate ganglion neurons innervating the tongue. J Neurophysiol 2000; 84: 1404-13.

42. Pawlow JP. The work of the digestive glands. (translated into English by WH Thompson). Charles Griffin \& Co. Ltd., London 1902.

43. Richardson CT, Feldman M. Salivary response to food in hu mans and its effect on gastric acid secretion. Am J Physiol 1986; 250: G85-91.

44. Feldman M, Richardson CT. Role of though, sight, smell and taste of food in the cephalic phase of gastric acid secretion in humans. Gastroenterology 1986; 90: 428-33.

45. Katschinski M, Dahmen G, Reinshagen M, et al. Cephalic stimulation of gastrointestinal secretory and motor responses in humans. Gastroenterology 1992; 103: 383-91.

46. Novis BH, Bank S, Marks IN. The cephalic phase of pancreatic secretion in man. Scand J Gastroenterol 1971; 6: 417-21.

47. Fischer U, Hommel H, Ziegler M, Michael R. The mechanism of insulin secretion after oral glucose administration. I. Multiphasic course of insulin mobilization after oral administration of glucose in conscious dogs: Diabetologia 1972; 8: 104-10.

48. Richardson CT, Walsh JH, Cooper KA, et al. Studies on the role of cephalic-vagal stimulation in the acid secretory response to eating in normal human subjects. J Clin Invest 1977; 60: 435-41.
49. Teff KL, Engelman K. Palatability and dietary restraint: Effect on cephalic phase insulin release in women. Physiol Behav 1996; 60: 567-73.

50. Wicks D, Wright J, Rayment P, Spiller R. Impact of bitter taste on gastric motility. Eur J Gastroenterol Hepatol 2005; 17: 961-5.

51. Pouderoux P, Veyrac M, Michel $H$. Sham feeding disrupts phase III of the duodenal migrating motor complex in humans. Neurogastroenterol Motil 1995; 7: 139-44.

52. Stern RM, Jokerst MD, Levine ME, Koch KL. The stomach's response to unappetizing food: cephalic-vagal effects on gastric myoelectric activity. Neurogastroenterol Motil 2001; 13 : 151-4.

53. Waluga M. Wpływ aferentnej wagalnej stymulacji smakowej przy zastosowaniu czterech smaków na mioelektryczną czynność żołądka w okresie międzytrawiennym i poposiłkowym oraz na kinetykę opróżniania żołądka. Rozprawa habilitacyjna Nr 2/2010, Śląski Uniwersytet Medyczny, Katowice 2010.

54. Kasicka-Jonderko A, Jonderko K. Mental and physical stress modulation of the interdigestive gastric myoelectrical activity. In: Neurogastroenterology - Falk Symposium 112. Singer MV, Krammer HJ (eds.). Dordrecht/Boston/London: Kluwer Academic Publishers 2000; 560-4.

55. Levine ME, Muth ER, Williamson MJ, Stern RM. Protein-predominant meals inhibit the development of gastric tachyarrhythmia, nausea and the symptoms of motion sickness. Aliment Pharmacol Ther 2004; 19: 583-90.

56. Williamson MJ, Levine ME, Stern RM. The effect of meals of varying nutritional composition on subjective and physiological markers of nausea in response to optokinetic motion. Digestion 2005; 72: 254-60.

57. Brillat-Savarin JÁ. Physiologie du goût ou méditations de gastronomie transcendante. Ouvrage théorique, historique et à l'ordre du jour. Dédié aux gastronomes parisiens. Quatrième Édition. Just Tessier, Libraire, Paris 1834.

Received: 19.10.2013

Accepted: 23.12.2013 